\title{
Research on the Influence of Technical Barriers to Trade on China's Exports: Take Electronic Products Industry as an Example
}

\author{
Ke Zhang \\ School of Economics, Yunnan Minzu University, Kunming, China \\ Email: zk0215@gmail.com
}

How to cite this paper: Zhang, K. (2020). Research on the Influence of Technical Barriers to Trade on China's Exports: Take Electronic Products Industry as an Example. Open Journal of Social Sciences, 8, 383-392.

https://doi.org/10.4236/jss.2020.88032

Received: August 6, 2020

Accepted: August 24, 2020

Published: August 27, 2020

Copyright $\odot 2020$ by author(s) and Scientific Research Publishing Inc. This work is licensed under the Creative Commons Attribution International License (CC BY 4.0).

http://creativecommons.org/licenses/by/4.0/

\begin{abstract}
With the continuous improvement of China's economic strength and scientific and technological level, China's foreign trade is also developing rapidly, and technology trade is also prospering. Now it has become an important part of China's foreign trade. At the same time, with the increasing trade friction, the export of electronic products in China is constantly affected by technical barriers to trade. By studying the short-term and long-term stages of TBT, this paper analyzes its mechanism and its impact on the export and welfare of electronic products in China, discusses its causes and puts forward corresponding countermeasures and suggestions.
\end{abstract}

\section{Keywords}

Technical Barriers to Trade, Electronic Products Export, Foreign Trade

\section{The Introduction}

Technical Barriers to Trade (TBT) means that it appears in the form of national or regional technical regulations, agreements, standards and certification systems (conformity assessment procedures), covering many technical index systems such as science and technology, health, quarantine, safety, environmental protection, product quality and certification. In international trade, there are flexible, changeable and numerous regulations. Technical barriers to trade appear in large numbers by technical means, so they often put on a legal cloak and become the most concealed, most difficult to deal with, and the most commonly used non-tariff barriers in current international trade. Technical barriers to trade restrict the products of non-developed or technologically backward countries through the establishment of strict technical regulations and technical thre- 
sholds by developed countries or technologically advanced countries. They are nominally to safeguard the safety of countries and regions, and protect human life and health. The ecological environment is actually to restrict the entry of goods, investment and services from other countries and to protect the domestic market. Therefore, technical trade barriers are widely adopted by countries as an important means to protect their domestic markets and industries and promote foreign trade.

Although China is the largest trading country in the world, it often encounters the impact of technical barriers to trade due to its low technical content and lack of innovation. According to data released by the ministry of industry in China, the 2014 export enterprises in our country suffered a direct loss of technical barriers to trade above $\$ 75.52$ billion, 2016; the technical trade barriers to China has reached $\$ 93.38$ billion; the economic losses is caused by the additional cost of $\$ 24.75$ billion, and by more than $40 \%$ above; the export enterprises encounter the technical barriers to trade. Since China's accession to the WTO, $80 \%$ of the trade barriers encountered in international trade are technical barriers to trade, and the export volume affected by TBT accounts for about $25 \%$ of the total export volume ${ }^{1}$. According to the latest information of the trans-pacific partnership agreement shows that the rules of world trade in goods will further be highly compatible with intellectual property rights, environmental protection, and technical standards. This will also cause China to face more technical trade barriers in the future, and will also affect China's various industrial exports in the next time.

\section{Literature Review of Technical Barriers to Trade at Home and Abroad}

Technical Barriers to Trade (TBT) originated from developed countries and regions and was widely concerned by theoretical circles at home and abroad in the late 1970s. As for the mechanism that smuggles TBT into a country's market, we believe that it will bring irreversible sunk costs, which in turn will affect the export decision of enterprises. Bolin Ye on the research background of the technical barriers to trade, show that in the second world war, the development of world trade liberalization, traditional trade barriers, countries to look for new trade barriers is the direct cause of its produce, and the new trade barriers and direct trade between countries export (Ye, 1999); Markusen think technical barriers to trade can cause additional costs to produce and export, the extra cost including fixed cost and variable cost, because different importer of technical regulations and standards vary, this makes the fixed costs of each market all have differences, also makes the enterprise when doing the export decisions will spontaneous choice with low barriers to entry in the market, or don't export, thus affecting trade flows. Therefore, technical barriers to trade, as a kind of cost increasing barriers, affects the export decision of enterprises, so that the flow of international trade changes (Maskus \& Wilson, 2001). However, Wenshu Gao and Jie ${ }^{1}$ Data source Xinhuanet: http://www.xinhuanet.com/politics/2015-10/20/c_128336358.htm. 
Wang argue that TBT is caused by the economic differences of various countries and the incomplete information of market mechanism (Gao, 2003).

In the existing literature, all think roughly the technical trade barriers on exports and benefits there is a positive or negative impact: Cao and Johnson by studying in New Zealand to enforce beef and mutton in risk management and evaluation system, found that red meat exports growth significantly, thus confirm the exporter of the standard trade promotion effect (Cao \& Johnson, 2006). Chunming Zhao and Hao Chen established the two-country model and used the game theory to conclude that as long as the technological gap between the two countries is not large, even if the technological barriers erected by the non-dominant countries can bring benefits and increase exports to their own countries. Junjun Hou also showed through empirical research that the improvement of national standards would promote the increase of export trade in the long run. However, through empirical research (Hou, 2009), Moenius believes that the heterogeneous standards of importing countries will reduce the export of trade but promote the import. In the analysis of china-South Korea trade gravity model (Moenius, 1999), Xiaojuan Chen and Yueying $\mathrm{Mu}$ found that the technical trade barriers set by South Korea had an obvious nature of trade protectionism, which inhibited China's agricultural exports to South Korea (Chen \& Mu, 2015). Bao Xiaohua and Daming Zhu after building the nonlinear gravity model, and studied the difference of the exporter encounters TBT, found that the higher the per capita income level, production technical level is higher, the higher the government management ability can have more high TBT coping, and makes a long-term TBT may positive contribution to a country's exports, its benefits may also be positive (Bao \& Zhu, 2015).

\section{Analysis of the Influence of TBT on Export and Welfare in Short and Long Term}

\subsection{The Impact of TBT in the Short Term}

TBT has a negative impact on exporting countries in the short term. First of all, we can illustrate from the S-D curve, as shown in Figure 1. D is the demand curve of importing country, $\mathrm{S}$ is the supply curve of exporting country, $\mathrm{E}$ is the initial trade equilibrium point, and $\mathrm{Pe}$ is the initial price equilibrium point. Exporters now importing countries technical barriers to trade, in order to deal with TBT, in a short time needs through negotiation or pay additional costs, which in turn makes the $S$ curve to move above again, and the elasticity decreases, and the $S$ curve moves to $S^{*}$, assuming that importer $\mathrm{D}$ curve remains the same, so export prices will rise, and become a $\mathrm{P}^{\star}$, exports also decreased.

Secondly, we can also analyze the impact of technical barriers to trade on exports according to the terms of trade. The mechanism is as follows: when TBT is implemented, China's commodities cannot meet the technical requirements of the importing country in a short period of time, so the export volume decreases rapidly, and some unmarketable commodities flow back to China, leading to the decline of domestic prices, the decline of export prices, and the deterioration of 


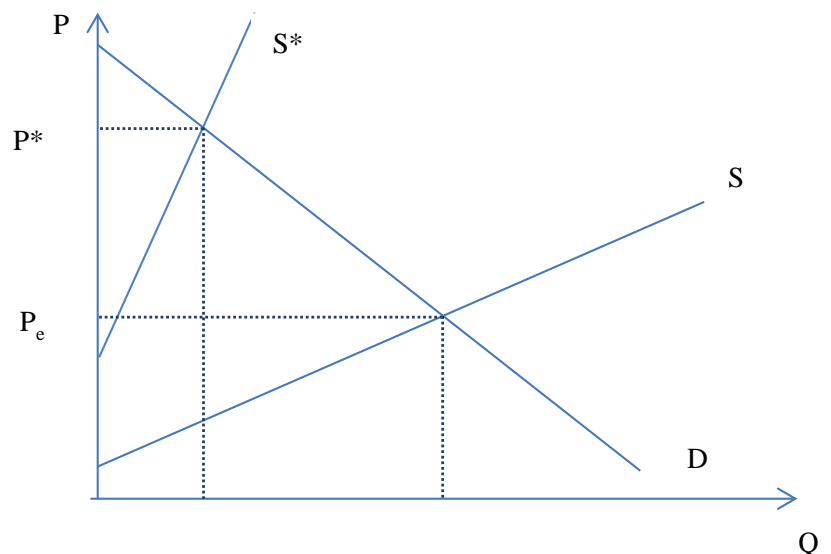

Figure 1. The impact of TBT in the short term: S-D curve.

terms of trade. As shown in Figure 2, $\mathrm{M}$ represents imported goods, $\mathrm{X}$ exports goods, OE represents the curve provided by the importing country, OF represents the curve provided by the exporting country, OF represents the curve provided by the exporting country after the implementation OF TBT. The equilibrium point before the implementation OF TBT is Point E, and the equilibrium point after the implementation OF TBT is point $\mathrm{E}^{\star}$, and the terms $\mathrm{OF}$ trade are $\mathrm{OE}$ and $\mathrm{OE}^{\star}$ respectively.

After the implementation OF TBT, the improvement curve OF the exporting country will change to $\mathrm{OF}^{*}$ due to the increase OF sunk costs and additional costs. As can be seen from the figure, the terms $\mathrm{OF}$ trade will deteriorate to $\mathrm{OE}^{\star}$ and the export volume will decrease.

\subsection{The Long-Term Effects of TBT}

TBT has a positive impact on exports in the long run. According to the "imitation gap model", technological innovation can promote trade, and continuous technological innovation will make import and export trade continue. The mechanism is as follows: when the importing country begins to implement TBT, the exporting country will produce trade inhibition effect in a short period of time, but in order to continue the trade, the exporting country will carry out technological innovation over TBT for a period of time. In addition, due to the non-saturation of consumer preference, the emergence of new technology will increase the demand of importing country. Therefore, in the case of constant supply, increased demand will lead to an increase in exports.

In time, under the action of each country and enterprise facing the technical barriers to trade is not always the same, with the development of science and technology, new technology constantly appears, so BT will follow the ascension of the new technology constantly improve themselves, so the importer will also continuously improve product quality requirements, so the technical barriers to trade and in the process of technological innovation and stimulate exports has realized the dynamic circulation and upgrade. As shown in Figure 3, the pro- 
duction and trade curve of an enterprise is $S_{1}$. The horizontal axis represents the rate of change of trading volume to time $\mathrm{Q} / \mathrm{T}$, and the vertical axis represents the upgrading degree of technical trade barriers. It can be seen from the figure that technical trade barriers are rising dynamically as time goes on. At the beginning, when the technical barrier was $T_{0}$, the trading volume of $S_{1}$ was $Q_{0}$; when the technical barrier was developed to $\mathrm{TBT}_{1}$, the trading volume dropped to $\mathrm{Q}_{1}$; with the promotion of time and the update of technology, the traffic volume at $\mathrm{TBT}_{2}$ was reduced to $\mathrm{Q}_{2}$. At this point, if an enterprise begins to break through technical trade barriers and carry out product upgrading and technological innovation, the production trade curve will shift to the right to the $S_{2}$ line. At $T_{0}$, the trading volume reaches $\mathrm{Q}_{0}{ }^{*}$. With the increase of technical barriers $T_{1}$ and $T_{2}$, the trading volume will also increase to $\mathrm{Q}_{1}{ }^{*}$ and $\mathrm{Q}_{2}{ }^{*}$. Therefore, with the increasing requirement of technical trade barriers and the continuous innovation of enterprises, the technological level and trading volume of the whole world are also improved in the game between them.

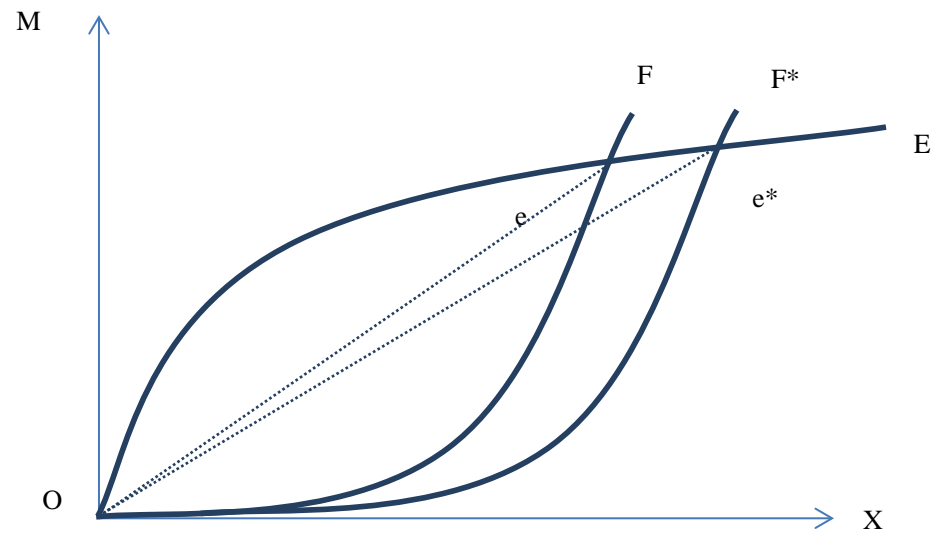

Figure 2. The impact of TBT in the short term: the terms of trade.

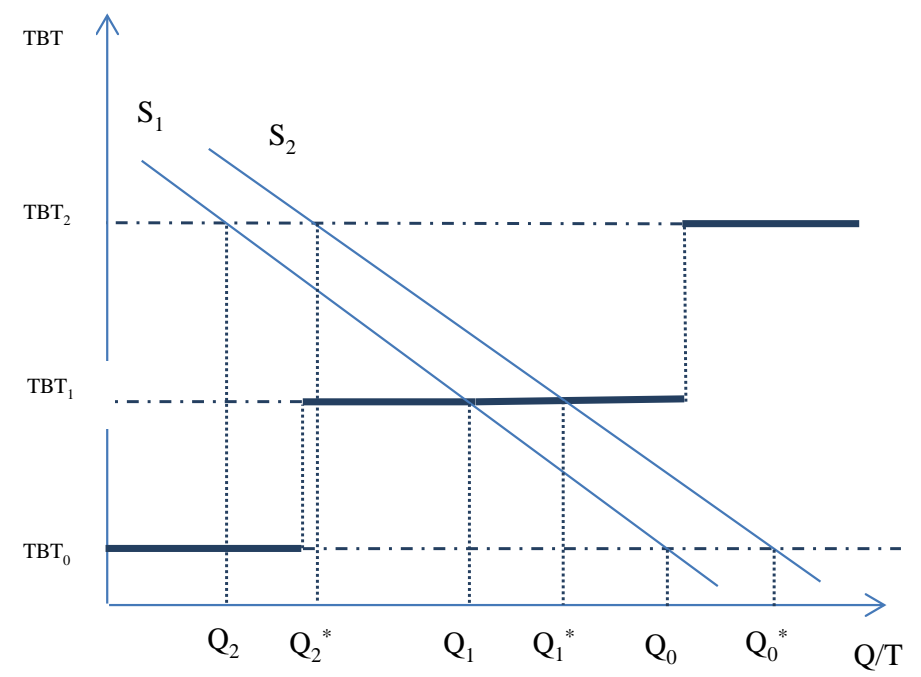

Figure 3. The long-term effects of TBT: imitation gap model. 


\subsection{The Influence of Technical Barriers to Trade on Industry Welfare}

Technical trade barrier also can produce obvious effect to industry welfare. As shown in Figure 4, China and foreign countries are the export and import countries of a certain commodity respectively. The horizontal axis represents the supply and demand quantity of the commodity, the left axis represents China, the right side represents foreign countries, and the vertical axis represents the price of the commodity. SX, DX, SM and DM are the supply and demand curves of exporting and importing countries respectively. $\mathrm{PW}$ is the transaction price under free trade conditions. If foreign countries now impose technical trade barriers on China's export commodities, China will passively improve the technical quality of export commodities, and the price will also be increased due to technical inputs such as R\&D and quality improvement, and the transaction price of new products will be P2. Imports will fall as prices rise. Due to the backflow of some commodities in The Chinese market, the domestic price is reduced to P1, so will the export volume. Therefore, China's consumer surplus will increase the area of $\mathrm{D}+\mathrm{E}$, while the producer surplus will decrease the area of $\mathrm{A}+\mathrm{B}+\mathrm{C}+\mathrm{D}$ $+\mathrm{E}$, while the exporter will gain the area of $\mathrm{B}+\mathrm{F}$ by virtue of their technical advantages. Therefore, due to the implementation of technical barriers, the net impact of industry welfare effect will be F-A-C. Therefore, the positive and negative of industry net welfare depends on the respective size of F, A and C.

\section{A Case Study of China's Electronic Products Export Encounter TBT from the United States}

Electronics is one of the most important export industry in China the development of electronic products is not only related to the development of the electronics industry in our country, also with the development of the electronics industry in our country, and electronic products export market in our country, the United States is China's largest export country, at the same time, our country is the largest country in the affected by the TBT.

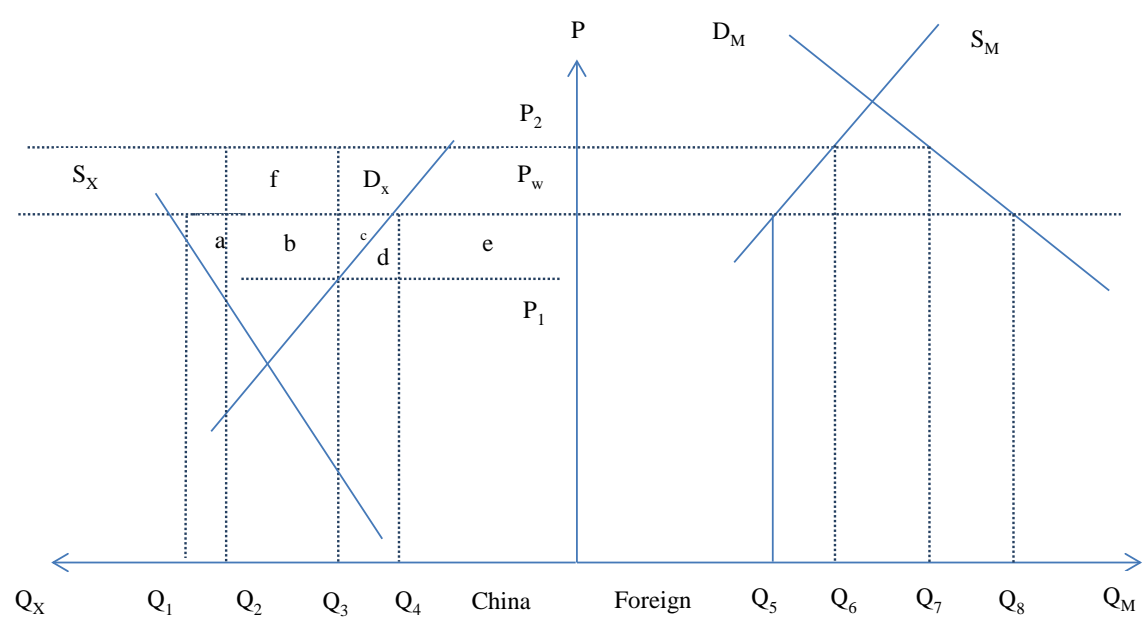

Figure 4. The influence of technical barriers to trade on industry welfare. 
This paper will analyze the data of electronic products exported from China to the United States in recent years, so as to discuss the impact of technical barriers to trade in the United States on China's electronic products.

According to the law of the People's Republic of China Ministry of Industry and Information Technology published data available electronic products exports to the United States in China, in 1993 China's exports to the United States electronics trade totaled $\$ 1.95$ billion, China to become the second largest importer of electronic products, the US market since then, China's rapid growth of electronic products exports to the United States, from 1995 to 2001 in just six years, China's total trade rose from $\$ 3.69$ billion to $\$ 10.64$ billion, and since 2002, due to the impact of technical barriers to trade in the United States, the percentage increase short-term slowdown, but total trade is still increasing year by year, In 2007, China's export volume of electronic products to the United States exceeded 50 billion US dollars. In 2016, China's export volume of electronic products reached 93.16 billion US dollars. It can be seen from this that with the continuous development of Sino-American trade, the volume of China's electronic products exported to the United States is also expanding. By China's export trade on electronic products to the United States can be found that since 2001, the electronic products trade, China's exports to the United States, has shown a steady rise in status, in 2001 China's exports to the United States of electronic products trade for $\$ 10.64$ billion, for $\$ 93.16$ billion to 2016 , during this period, China's overall trade shows continued positive growth trend. According to Figure 5, it can be seen more intuitively that China's export of electronic products to the United States is gradually tending to be reasonable and stable.

When China's foreign trade is developing rapidly, the United States frequently uses safety, green, environmental protection and other excuses to constantly implement technical trade barriers against China's electronic products export, so as to achieve the purpose of protecting the American own electronic industry and protecting the interests of its consumers. According to the latest statistics of the Ministry of Industry and Information Technology, China has nearly 70 percent of electronic manufacturers, more than 40 percent of electronic products have encountered the United States set up technical barriers to trade, the annual loss of tens of billions of dollars, it can be seen that China's electronic products export is facing the United States technical barriers to trade serious restrictions.

With the continuous progress of science and technology and the continuous improvement of consumer demand, consumers' dependence on electronic products is also increasing. At the same time, indicators of all aspects of electronic products must also be constantly improved. The United States has issued more and more technical trade barriers to electronic products, so China's electronic products export trade is facing an increasingly difficult situation. Among them, electronic products, such as electronic components, household consumer goods, computers and communication equipment, face the most significant technical barriers to trade in the United States. 


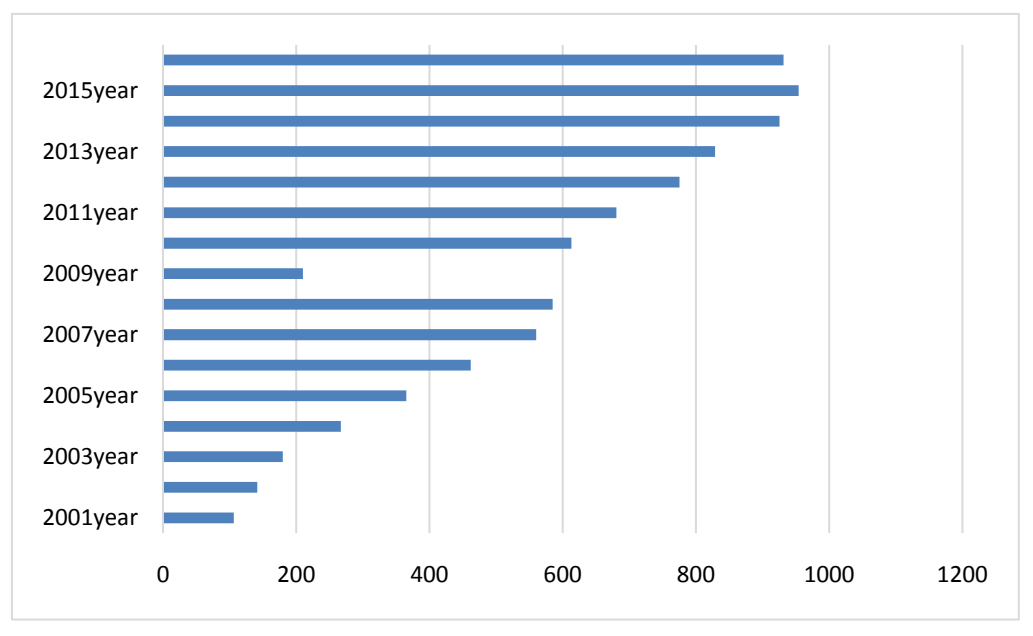

Figure 5. China's total export of electronic products to the United States: 100 million yuan.

Table 1 and Figure 6 show the four categories of 2016, China's electronic products exported to the United States trade and trade barriers in the corresponding index, index of trade barriers I on behalf of the United States the establishment of technical trade barriers affect the class electronic products within the range of 20\%; Barriers to trade index II on behalf of the United States the establishment of technical barriers to trade affects the range of $20 \%$ to $40 \%$ of the electronic product; III trade barriers index to represent the United States the establishment of technical trade barriers affect the range of this kind of electronic products for more than $40 \%$.

In recent years, with electronic products export trade in our country, our country's electronic products in the export process has encountered technical barriers to trade restrictions in the United States, the most typical event is "Blocking Huawei and ZTE event": in 2015 the United States intelligence committee banned Huawei and ZTE electronic products mainly export enterprises in our country. During this period, as the technology of electronic products in China could not be improved in time, the export volume showed a downward trend. As shown in Figure 7, since June 2015, China's export volume of electronic products has shown a trend of decline. It can be seen from this that technical trade barriers have played a role in inhibiting the export of electronic products in the short term.

Through the above data and theoretical analysis, we can know that the implementation of TBT in the United States, for example, will hinder the export of electronic products in China in the short term. This is because in the short term, enterprises are still unable to face higher barriers costs and carry out technological innovation quickly. In the long run, it has a promoting effect, because in the long run, more understanding of new technical standards in technical barriers to trade, can develop better products to expand the market, thus driving the increase in consumption, and then increase in exports. 


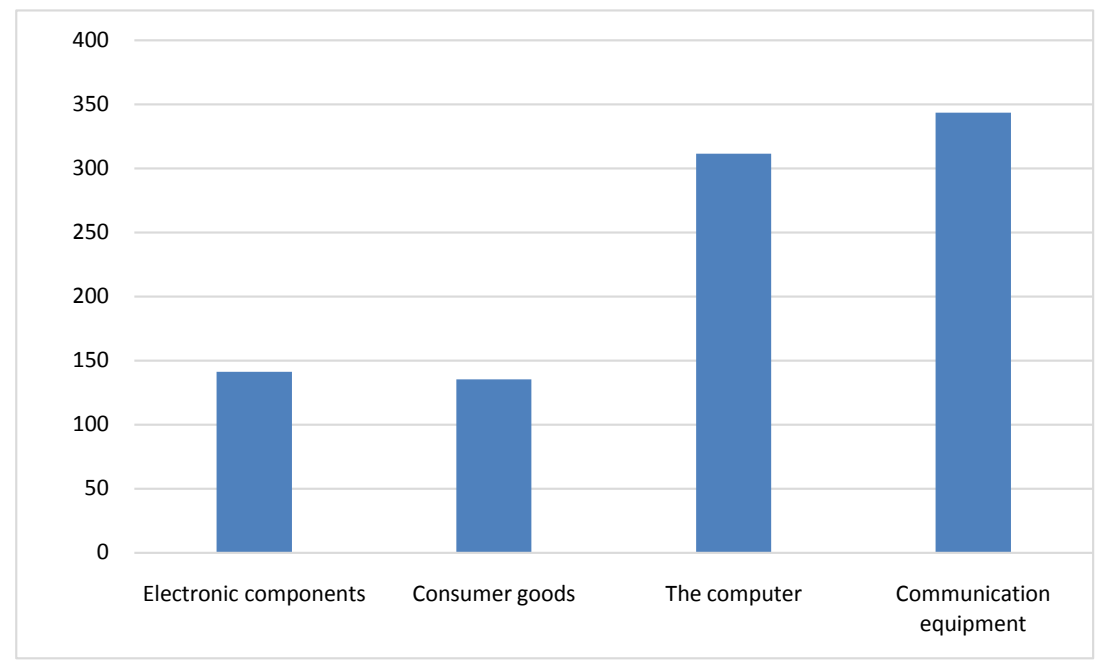

Figure 6. Trade volume of China's electronic products exported to the United States in 2016 (US $\$ 100$ million).

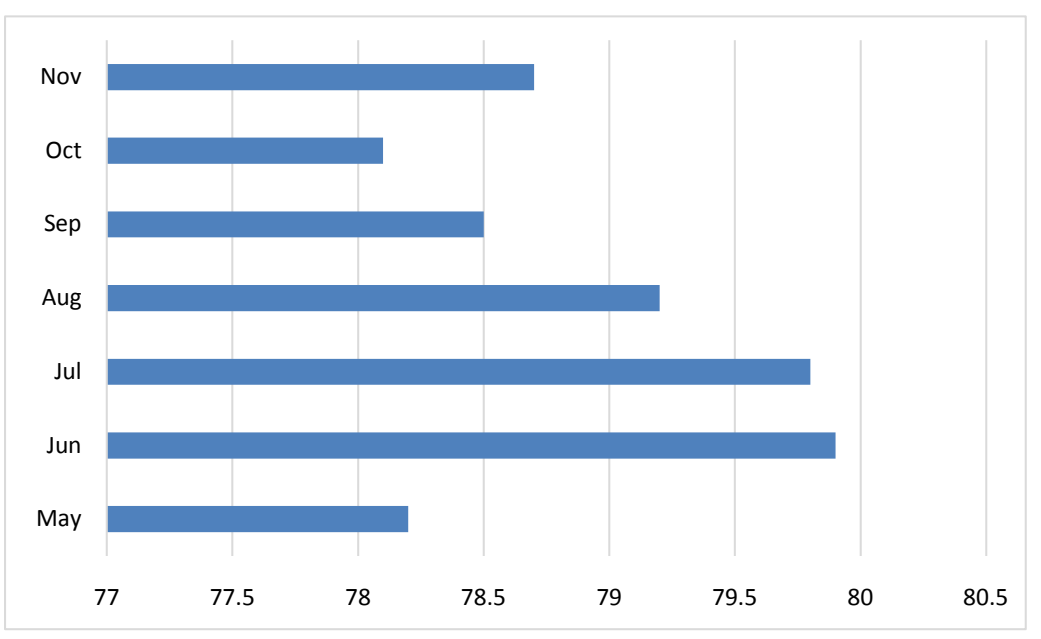

Figure 7. The amount of China's electronic products exported to the United States from May 2015 to November 2015 (US \$100 million).

Table 1. The trade barrier index of China's electronic products exported to the United States in 2016.

\begin{tabular}{ccccc}
\hline \multicolumn{4}{c}{ The trade barrier index of China's electronic products exported to the United States in 2016} \\
\hline $\begin{array}{c}\text { Category of Electronic } \\
\text { Products }\end{array}$ & $\begin{array}{c}\text { Electronic } \\
\text { components }\end{array}$ & $\begin{array}{c}\text { Consumer } \\
\text { goods }\end{array}$ & $\begin{array}{c}\text { The } \\
\text { computer }\end{array}$ & $\begin{array}{c}\text { Communication } \\
\text { equipment }\end{array}$ \\
Barriers to index & I & II & II & III \\
\hline
\end{tabular}

\section{Policies and Recommendations}

China's electronic products in the export trade encountered technical barriers to trade problems, in most cases, because China's understanding of technical barriers to trade is not enough, but also some countries in the process of setting up technical barriers to trade and implementation is full of hide and other reasons. Therefore, in the current situation of trade pattern, we should strengthen the re- 
search and study of technical barriers to trade, and accelerate the realization of our electronic products to the technical barriers to trade across.

At the same time, our country should also actively respond to bring the negative impact of trade barriers, and starting from the long-term interests of our country, combine the actual conditions of our country national condition, such as the level of productivity development, scientific and technological level, environmental conditions, etc. seriously and formulate internal technical innovation policies, and implement the strategy of "innovation to promote the reform", so as to provide the conditions for realizing technological leapfrogging.

\section{Conflicts of Interest}

The author declares no conflicts of interest regarding the publication of this paper.

\section{References}

Bao, X. H., \& Zhu, D. M. (2015). Differentiation Effect of Technical Barriers to Trade: International Experience and Its Enlightenment to China. The World Economy, No. 11, 71-89.

Cao, K., \& Johnson, R. (2006). Impacts of Mandatory Meat Hygiene Regulations on the New Zealand Meat Trade. Australasian Agribusiness Review, No. 14, 3-15.

Chen, X. J., \& Mu, Y. Y. (2015). Analysis of the Influence of Technical Barriers to Trade in Korea on China's Agricultural Exports. Exploration of Economic Problems, No. 7, 121-127.

Gao, W. S. (2003). Economic Analysis of Technical Barriers to Trade. Finance and Economic, No. 9, 58-63.

Hou, J. J. (2009). Standardization of China's Foreign Trade Development Research. Changsha: Hunan University.

Maskus, K. E., \& Wilson, J. S. (2001). Quantifying the Impact of Technical Barriers to Trade: A Review of Past Attempts and the New Policy Context.

Moenius, J. (1999). The Bilateral Standards Database (BISTAN) Technical Reference Manual. San Diego, CA: Mimeo University of California.

Ye, B. L. (1999). Some Standard Problems Encountered in the Development of ExportOriented Economy. The Standard of Science, No. 6, 2-30. 